\title{
Between Tradition and Automation in Special Collections: A Memoir
}

Insofar as my career in libraries straddled the time when "scholar librarians" dominated special collections to the time when "techie librarians" had pretty much taken over, and as I was in the middle of this change at several institutions, I would like to offer a few observations on this radical transition in special collections librarianship.

\section{Early Days}

My first library job was in 1973 in the cataloging department of Bowdoin College. A few weeks after I started, this library entered the computer age by acquiring its first OCLC terminal. OCLC had been founded in 1967 as the Ohio College Library Center, had gone live in 1969 with its first online bibliographic record, had signed by April 1970 only three libraries to receive catalog cards, had input only 150,000 records by December $1970,{ }^{2}$ and in 1972 was just beginning to become a national presence. The whole Bowdoin library staff was fascinated by this innovative electronic gizmo. Some gawked at it, some were bewildered by it, some felt that it was unnecessary, some were offended by the ugliness of the catalog cards that it would generate, and some dedicated themselves to serious study to learn how to use it.

All the professional librarians then at Bowdoin had the MLS or its equivalent-except the special collections librarian, who had a $\mathrm{PhD}$ in European history and no formal library training. I was surprised at this but impressed at the same time. I knew nothing about special collections, rare books, or archives, but I began to wonder: what was different about this part of the library? ${ }^{3}$ Why would a scholar, rather than a "real" librarian, be in charge of it?

1. I am most grateful to Lynne Prunskus, former University Archivist and Head of Special Collections in the James A. Gibson Library of Brock University and former Associate Director of Libraries at Nipissing University, for her substantial contributions to the earliest versions of this paper; and to my wife, Diane, reference librarian par excellence, for her work and support. Private communications and ExLibris-L posts from Gabriel Austin, Shelley Cox, Jackie Dooley, Gail Edwards, Maggie Exon, Justin W. Fox, Gene Freeman, Tanya Elder, Bruce Henstell, Eric Holzenberg, Jack Kessler, Anna Kirkwood, Anne Marie Lane, Al Luft, Barry Neavill, Mark Purcell, Louis Reith, Marvin Taylor, Peter Uva, Germaine Warkentin, Everett Wilkie, and Kathleen Wrest have been very helpful—which is not to imply that any of these people agree with me. I also acknowledge the wise guidance of my mentors in librarianship and rare book curatorship: Christine Ruggere, Penny Schwind, Bruce McKittrick, Terry Belanger, Michael Winship, John F. Dean, the late Willman Spawn, the late Peter Graham, the late Sue Murray, the late Kathryn Wright, and especially the late Joe Derbyshire.

2. Ohio College Library Center, Annual Reports 1967/1968-1970/1971 (Columbus: Ohio College Library Center, 1971).

3. William L. Joyce, "The Evolution of the Concept of Special Collections in American Research Libraries," Rare Books and Manuscripts Librarianship 3, no. 1 (Spring 1988): 19-29. 


\section{College of Physicians of Philadelphia}

In 1980 I was hired-I believe on the basis of my facility with European languages-as Historical Collections Assistant at the College of Physicians of Philadelphia (hereafter, "CPP"). I knew nothing about either medicine or the history of medicine. However, since my duties would include scholarly reference work as well as cataloging rare books, I made it my immediate business to cram as much relevant subject knowledge into my head as quickly as possible on my own time.

Working at CPP was the best training a rare-book librarian could get. I learned not only how to do full-level descriptive cataloging of rare books with tracings for bindings, provenance, and several other special access points, but also how to investigate queries in the history of medicine to the best advantage of each particular user. I learned that "one size does not fit all" library users; for example, a physician and a professional historian, even though they might ask a librarian the same question, have different needs - which the librarian must discern — and thus do not expect the same response, the same information, the same sources, the same depth, or the same level of attention.

The most important aspect of any kind of librarianship is the relation between librarians and the users of the collections. Librarianship is a service profession whose ultimate goal ought to be the prompt, efficient, enlightened, and complete satisfaction of each user's legitimate needs. This is accomplished mostly through reference interviews and their aftermath. Surely there are technical skills involved in conducting proper reference interviews, and these skills can be learned in library schools and practiced in internships; but we should recognize that even the most skilled reference interviewer-if that person is only a librarian - is capable of dealing adequately only with ordinary users, the general public, and undergraduates. To address properly the needs of graduate students, professors, and postgraduate scholars, librarians must also have an appropriate measure of subject expertise commensurate with these researchers' respective needs. I would argue that, at that level, the librarians' subject expertise is more important (that is to say, more beneficial to the users) than reference interviewing skills. This is because graduate students, professors, and postgraduate scholars - unlike ordinary users, the general public, and undergraduates - typically already know exactly what information they want when they enter a library, so it is up to librarians to understand their queries in sufficient depth and with sufficient accuracy to be able to retrieve this information quickly, cleanly, intelligently, and in a thoroughly documented way. Thus librarians become, in effect, collaborators in their users' research. ${ }^{4}$

4. Daniel Traister, “The Rare Book Librarian’s Day,” Rare Books and Manuscripts Librarianship 1, no. 2 (Fall 1986): 93-105. 
In special collections we try to achieve a happy medium between two kinds of service: (1) traditional, slow, painstaking, sometimes elitist, but scholarly and accommodating; and (2) technological, efficient, automated, more democratic, but unscholarly and impersonal. A preeminent scholar in the history of medicine recently lamented that "over the course of my three decades in the field, medical libraries have shifted from busy places filled with students to underfunded, threatened spaces where students rarely go; even history students tend to avoid them. Books, journals, and papers are being 'weeded' in favor of computers. As a historian in a medical school, I want future doctors to know that ... they must remember to look for books." ${ }^{.5}$ She is exactly the type of user whom we special collections librarians treasure.

During the two years that I was at CPP, I also learned how to do genealogical searches; became personally acquainted with many rare book dealers; learned how to evaluate their sales catalogs; and helped on an ad hoc basis with preservation, conservation, restoration, and disaster planning as CPP recovered from a devastating 1978 flood. ${ }^{6}$ CPP's use of computers was minimal and rather cumbersome. It used OCLC for copy cataloging but was not yet allowed to input original cataloging. It had a Byzantine dial-up connection to the National Library of Medicine's Catline. As one of ten Regional Medical Libraries, it had semiautomated document delivery to facilitate its role as a major interlibrary loan supplier. But I bought my first computer in 1981, an IBM PC, and taught myself not only how to use it, but also how to program it and even how to do a little hacking. From 1983 to 1996, I was the associate editor of an academic philosophy journal. After 1985, the editor and I lived 300 miles apart, so we went online and did most of our business that way. We both became proficient on the Internet before most people even knew there was such a thing.

\section{Upstate Medical University}

In 1987 I became Curator of Historical Collections at Upstate Medical University, which had been looking for its first special collections librarian, not only to found the department, but also to bring it quickly up to current technological standards. I told them that I had no MLS and no formal library training, but that I had extensive experience with cataloging, special reference, computers, preservation, book repair, acquisitions, historical scholarship, and writing for publication. I was hired on the spot. Among other things, the library director expected me to augment the collection, publicize it nationally, curry favor among physicians and medical historians, and eventually write the definitive history of Upstate, a task which I completed

5. Jacalyn Duffin, "Library Adventures in a Digital Age: Observations and Questions," RBM 15, no. 2 (Autumn 2014): 98.

6. Christine Ruggere and Elliott H. Morse, "The Recovery of Water-Damaged Books at the College of Physicians of Philadelphia," Library and Archival Security 3, no. 3 / 4 (Fall/Winter 1980): 23-28. 
in 2005. ${ }^{7}$ She told me flat out that my PhD was worth more to her than an MLS would have been.

When I arrived at Upstate, it was already far ahead of most libraries in computerization and automation. In 1968, a year before OCLC went live, Upstate library director Irwin Pizer had introduced the world's first online bibliographic retrieval service. ${ }^{8}$ Upstate was proud of Pizer's achievement and, through cooperation among our tech-savvy librarians and the information technology department, we actively continued to try to stay in the forefront of library automation. We were not always successful, but we were daring, and we were typically among the first to try innovations in OPACs, bibliographic searching, CD-ROMs, and several other technologies.

\section{The MLS}

In 1992 the federal government offered me a grant to get a free MLS at Syracuse University (SU). I still did not feel that I needed this degree; I had already been a professional librarian for five years. But I went to library school full-time without reducing my Upstate hours and finished the degree in ten months. With my focus on automated systems and cataloging, I received a Certificate in Information Systems and Telecommunications Management along with my MLS.

Since getting the MLS in 1993, it has not gained me a single benefit. My professional life did not change one way or the other because of it. But I noticed one thing during those ten months that I had not previously realized: SU School of Information Studies faculty were in love with technology for its own sake and quite out of touch with what was actually happening in libraries. For example, I took a course in bibliographic searching, in which we learned all kinds of algorithms, strategies, terms, and quantitative data, but nothing whatsoever that would help a library user. I already knew how to search and how to give all kinds of users exactly what they wanted or needed. I felt that, with my practical experience, I could teach the teacher something about how searching is or ought to be done in the real world.

Until quite recently, it was a persistent conceit among special collections librarians that we got our jobs in spite of our MLS degrees. Indeed, it was often the case that the head of special collections would have a master's or a $\mathrm{PhD}$ in some academic discipline and no library degree at all. This breed is now mostly extinct. Nowadays, although the postgraduate degree in an academic subject is still regarded as of prime importance, it is not nearly so common for the head of special collections not to have also an MLS. Yet the head of special collections who has only an MLS

7. Eric v.d. Luft, SUNY Upstate Medical University: A Pictorial History (North Syracuse, N.Y.: Gegensatz Press, 2005).

8. Luft, SUNY Upstate Medical University, 150-51. 
and no postgraduate scholarly credentials remains scarce. This is how it should be. Moreover, library schools have been criticized for not providing adequate training for future special collections librarians. ${ }^{9}$ To acquire the most useful special collections librarian skills, a student should study history, languages, and literatures; should attend conservation and preservation workshops; and, once hired as a special collections librarian, should supplement this training with enrollment in continuing education courses at Rare Book School.

\section{Contemplation of Evolving Technology}

Researchers until the mid-1980s who required far-flung resources would have to spend tremendous amounts of time, money, and guesswork travelling, poring over tomes, manuscripts, and indexes, and still would sometimes come up empty. The early 1990s were pivotal for the transition from traditional to automated librarianship, as most repositories were by then using at least some degree of Internet communications ${ }^{10}$ to provide access. ${ }^{11}$ The microminiaturization of computers and their ensuing portability forced archivists and special collections librarians to improve the range and depth of their services. ${ }^{12}$ We have learned since that time that computerization increases the use of library catalogs. ${ }^{13}$ That is, OPACs have proven more popular than card catalogs, probably because users do not need to achieve a certain level of bibliographic skill before being able to search OPACs effectively. Keyword searching, which is nearly impossible in card catalogs, is typically sufficient in OPACs.

Besides this and other obvious advantages of OPACs for library users, librarians also benefit from OPACs being easier to create, ${ }^{14}$ maintain, ${ }^{15}$ and update ${ }^{16}$ than card catalogs. The days of mercury switch erasers, pulling and refiling card sets (hoping not to miss one), and memorizing ALA Filing Rules are over! Since then, however, it has become increasingly possible to search detailed records in OPACs worldwide,

9. Michèle V. Cloonan, "The Future (Imperfect) of Special Collections and Library School Education," Rare Books and Manuscripts Librarianship 10, no. 2 (Fall 1995): 65-72; William L. Joyce, "Educating and Training Special Collections Librarians," Rare Books and Manuscripts Librarianship 10, no. 2 (Fall 1995): 73-76.

10. Avra Michelson and Jeff Rothenberg, "Scholarly Communication and Information Technology: Exploring the Impact of Changes in the Research Process on Archives," American Archivist 55, no. 2 (Spring 1992): 236-315.

11. Carole Prietto, "Automating the Archives: A Case Study," American Archivist 57, no. 2 (Spring 1994): 372

12. Ronald F.E. Weissman, "Archives and the New Information Architecture of the Late 1990s," American Archivist 57, no. 1 (Winter 1994): 21.

13. Tirong arap Tanui, "Library Cataloguing: Relevance to Modern Library Users," Library Review 41, no. 3 (1992): 33-38.

14. Helen Hayden, "Creation of an Online Catalogue for a Special Collection: The Experience at WIT Libraries,” SCONUL Focus 53 (Winter 2011): 43-46.

15. Howard Pasternack, "Online Catalogs and the Retrospective Conversion of Special Collections," Rare Books and Manuscripts Librarianship 5, no. 2 (Fall 1990): 71-76.

16. Diana Loreman, "Automating the Antiquated: Revolutionizing the Card Catalog," Computers in Libraries 22, no. 3 (Mar. 2002): 32-36. 
seamlessly, almost instantaneously, without leaving one's own desk-and moreover, to see full text online via Google Books, Hathi Trust, Project Gutenberg, Open Library, and other general sources, as well as via the online displays of particular repositories. ${ }^{17}$ Hence, special collections themselves now need to justify their continued existence, ${ }^{18}$ and even libraries are no longer as important for research as they once were. ${ }^{19}$ Yet others have argued that worldwide digitization has made individual special collections even more valuable than before, because their enhanced visibility has underscored their uniqueness. ${ }^{20}$

I was thrilled in 1993 to receive my first long-distance e-mail reference question. Using only standard search engines (which then were quite primitive, typically either Archie or Gopher), ${ }^{21}$ a biographer from Georgia was able to discover on the Internet that precisely the resources he needed to complete his work were among the nineteenthcentury holdings at Upstate. Such examples have since become legion, ${ }^{22}$ and most special collections departments can now attract and serve international ${ }^{23}$ and local users with equal ease and efficiency. ${ }^{24}$ Not only OPACs, but also online displays, full-text scans, ${ }^{25}$ and other pragmatic forms of digital outreach quickly showed the superiority of graphic user interface (GUI) over text-based librarianship, both digital and analog. Such outreach can even introduce special collections to a wide variety of very young students, satisfying the full depth of their newly awakened curiosity without librarians having to worry about untrained hands pawing irreplaceable materials. ${ }^{26}$

In 1995, as the Internet was changing from a simple text-based interface and becoming the World Wide Web with GUI, I began contending that the Internet is a wonderful tool that can perform many important functions better and faster than we could do before, as well as many new, worthy, and heretofore unimagined functions, but that it is nevertheless a fallible tool and must always be used with

17. Donghee Sinn, "Impact of Digital Archival Collections on Historical Research," Journal of the American Society for Information Science and Technology 63, no. 8 (Aug. 2012): 1521-37.

18. Peter B. Hirtle, "The Impact of Digitization on Special Collections in Libraries," Libraries and Culture 37, no. 1 (Winter 2002): 42-52.

19. Daniel De Simone, "Rare Book and Manuscript Libraries in the 21st Century: A Report on the Symposium at Houghton Library, Harvard University," ABAA Newsletter 4, no. 2 (Winter 1993): 1, 10-13.

20. David Pearson, "Special Collections in a Digital Future," Art Libraries Journal 35, no. 1 (Jan. 2010): $12-17$.

21. Google debuted in 1998, Dogpile and HotBot in 1996, AltaVista and Yahoo in 1995, and WebCrawler and Lycos in 1994.

22. Gwen Bird, "Small-Scale Digitization Goes Big Time," College and Research Libraries News 72, no. 3 (Mar. 2011): 149-52.

23. Ron Chepesiuk, "Digitizing Rare Materials: Special Collections Go Global,” American Libraries 32, no. 5 (May 2001): 54-56.

24. Abby Smith, "Special Collections Stake Their Claim in the Electronic Age," CLIR Issues 2 (Mar./ Apr. 1998), available online at www.clir.org/pubs/issues/issues02.html\#special [accessed 24 April 2015].

25. Alan Cornish and Alex Merrill, "Enabling Integrated, Online Access to Special Collections," Technical Services Quarterly 27, no. 2 (Mar. 2010): 151-63.

26. Melissa Mandell, "Why Should I Care? The Legacy Center Archives Reaches Out to High School Students with Its New Website,” The Watermark 38, no. 1 (Winter 2014/2015): 16-19. 
circumspection and even skepticism. It is not something to depend on; it is something to apply. I claimed then, and still claim, that the most valuable service that the Internet provides is instantaneous personal communication among colleagues, users, and experts worldwide. Such communication need not be direct; it could also be in the form of listservs, professional or semiprofessional blogs such as "Blogis Librorum,"27 and even Facebook posts, Twitter tweets, or Instagrams.

Conscientious and thorough service to all sorts of users was also enhanced by the proliferation in the 1990s of helpful listservs for library professionals, which put us in instant contact with our most knowledgeable colleagues worldwide, thus bringing their expertise to bear on whatever particular problems we were confronting locally; it would earlier have either frustrated us or resulted in substandard performance.

Almost all of this improved service is the direct result of computerization. ${ }^{28}$ However, too many librarians get carried away with their love of computers, neglect their primary duty to create user-friendliness, and lean instead toward technocracy (the rule of technology) or even technophily (the uncritical acceptance of every technological innovation, whether it is useful or not). Even while embracing new computer hardware, software, and protocols, they still adhere to the letter rather than the spirit of cataloging rules and prefer not to use their imaginations to devise new access points.

Users want and expect more and better digital resources. ${ }^{29}$ They want immediate full-text response, not scrolling through thousands of hits. They also want depth and palpability. Digital access - even full-text with high-resolution images and accurate OCR—cannot provide everything that researchers need. ${ }^{30}$ Special collections must continue to depend primarily on physical artifacts rather than either digital materials or even digital access. ${ }^{31}$ Digital full-text scanning dramatically enables long-distance access to the actual content of collections, but the well-known questions of digital permanence and future readability remain unanswere ${ }^{32}$ —and there is no adequate substitute for the heft and feel of a hand-press quarto or the joy of actually holding in

27. A noteworthy entry in this blog is: Andrea Koczela, "Libraries and Special Collections: An Interview with Cristina Favretto," available online at blog.bookstellyouwhy.com/libraries-and-specialcollections-an-interview-with-cristina-favretto [accessed 29 March 2015].

28. Sarah Dorpinghaus and Heather Fox, "Time Is on My Side: Harnessing the Power of Automation for Efficient Archival Workflows," Kentucky Libraries 79, no. 1 (Winter 2015): 20-23; Marshall Breeding, "Technology Alternatives for Special Collections," Computers in Libraries 33, no. 9 (Nov. 2013): 19-22.

29. Valerie Harris, "How Can I Help You? Becoming User-Centered in Special Collections," Archival Issues 32, no. 2 (2010): 71-97.

30. Charles T. Cullen, "Is There a Digital Purgatory?" Journal of Library Administration 46, no. 1 (2007): 75-88; also in: Digital Information and Knowledge Management: New Opportunities for Research Libraries, ed. Sul H. Lee (Binghamton, N.Y.: Haworth, 2007; New York: Routledge, 2012), 75-88.

31. Peter S. Graham, "New Roles for Special Collections on the Network," College and Research Libraries 59, no. 3 (May 1998): 232-39.

32. Constance Rinaldo, Judith Warnement, et al., "Retooling Special Collections Digitisation in the Age of Mass Scanning," Ariadne 67 (July 2011): 99-106. 
your hand a letter penned by Frederick Douglass. The Internet can only supply serviceable, but ultimately unsatisfying, reproductions of such priceless cultural artifacts.

\section{Balancing Scholarship, Librarianship, and Technology}

Since the advent of OPACs and the consequent destruction of card catalogs, circulation records, call slips, pocket cards, and other physical data, many historians and other researchers have deplored the fact that we can no longer learn what readers may have read or how they may have organized their knowledge. We can no longer reconstruct extinct libraries from their surviving inventories, accession records, or shelf lists; infer provenance from copy-specific notes or other hard evidence; or trace authors' progress as they wrote their famous books. For example, scholarship would be so much better if we could know what books Marx, Gandhi, Swinburne, Woolf, and countless other luminaries requested in the Round Reading Room.

Using a physical card catalog requires several complex and specialized skills that were typically acquired via what we called "bibliographic instruction" (BI), but anyone who can use a computer can use an OPAC. I was fortunate in sixth grade to have had BI, and I was sure to give my own daughter BI when she was in second grade-but many were not so fortunate. Hence the frustration that many felt with card catalogs — and the joy they felt when libraries threw them away.

When I left the curatorship in 2006, the special collections shelf list and special reference files still existed on catalog cards, which I had maintained, not for sentimental reasons, but because they were familiar to me and I could work with them easily-since I had written most of them myself. Yet I would not blame any of my successors for getting rid of them.

For the sake of each library's users, a balance in special collections management must be struck between the extremes of "magicians" on the one hand and quantitatively oriented technocrats and technophiles on the other. That is, the best special collections librarians have both subject expertise and computer savvy-and are willing to share both. An excellent general reference librarian with an MLS but no subject expertise relevant to users' needs might spend forty-five minutes on a search and find nothing, whereas an excellent special collections reference librarian with no MLS but enough subject knowledge to qualify almost as the users' "fellow researcher" can identify immediately what is needed, know where to find it, and produce it apace ${ }^{33}$ - with minimal "magic." Computers are necessary in both cases; but, to paraphrase Kant’s famous dictum, "Gedanken ohne Inhalt sind leer, Anschauungen ohne Begriffe sind blind" 34 : "Computer savvy without subject knowledge is empty, subject knowledge without computer savvy is blind."

33. Cf. Fredson Bowers, Essays in Bibliography, Text, and Editing (Charlottesville: University Press of Virginia, 1975), 85-86.

34. Immanuel Kant, Critique of Pure Reason, A51, B75. 